\title{
鋳片バルジング検知技術の開発
}

片岡克仁 ${ }^{*}$ ，伊藤光宏*

\section{Development of Bulging Detecting Technology for Casting Billet}

\author{
Katsuhito Kataoka and Mitsuhiro Ito
}

\section{Synopsis}

Thin solidified shell of billet in a continuous casting process expands in pressure by liquid steel inside. The expansion called bulging is often followed breakout of the shell and result in an interruption of the casting process. To avoid the accident, a bulging detecting technology has been developed. Both contact and non-contact method have been examined. Result of inline experiments shows that the contact method is superior to the non-contact method, variation of the bulging measured by the contact method was $1.85 \mathrm{~mm}$ whereas it was $5.65 \mathrm{~mm}$ measured by the non-contact method. Further more a correlation between the bulging and casting speed was confirmed.

\section{1. 緒言}

連続鋳造中の鋳片において，凝固した薄い鋼（シェル） が, 内部の溶鋼 (液状) 静圧により外側に膨らむバルジン グと呼ばれる現象が起こる。このバルジングが進行する と, 角柱状の鋳片の場合, 早期凝固するコーナ部近傍の シェルが引っ張られ, ついには破断し, ブレイクアウトに 至る. 万が一, ブレイクアウトに至った場合, 設備復旧の ため数日から数週間の運転休止が発生する。これによる生 産ロスは非常に大きなものとなる.

連続鋳造では，まずモールド (鋳型) で溶鋼を固め，そ れを下方に引き抜きながら, 鋳片を形成する。モールド直 下には, ピンチロールなどの鋳片を保持もしくは圧下する ためのロール群がある.この位置においては, 鋳片は拘束 されているためバルジングが発生することは無い. しか し, それらの拘束領域を抜けた後では, バルジングを直接 的に抑制することは不可能で, 鋳造速度や鋳片の冷却速度 を制御して, 間接的にバルジングの進行を抑制することに なる. 従って, 鋳片のバルジング量を監視し, 状況に応じ た抑制を施すことが重要である。一方, 従来のバルジング 検知技術は, 鋳片を直接測定するのではなく, モールド内
の溶鋼湯面の変動周期やパターンからバルジングやブレ イクアウトを予知している。これでは, バルジングの進行 に則した抑制を施すことは困難である.

そこで, 本研究では, 鋳造中鋳片の拘束領域を抜けた後 での鋳片形状を把握するために, 鋳片バルジング量を検知 する技術を開発した。

\section{2. 開発目標}

バルジングを把握する手段には, 投受光素子を用いて鋳 片の陰影から把握する方法, 鋳片側面の放射エネルギーを 撮像し得られたエネルギー分布 (熱画像)より把握する方 法，鋳片までの距離変位から把握する方法が考えられる. 投受光による方法では, 得られた形状が鋳片の傾きや回転 によるものか, バルジングによるものかを判断するのは困 難である．また，熱画像の方法では，鋼種や鋳造条件によ る温度差があり，同じ基準で全鋼種のバルジングを把握す るのが困難である。距離変位の方法では, 複数点計測し, 各点の相対变化からバルジング量の把握が可能であり, ま た, 1 点計測であっても, 鋳片が傾かない場合には, 経時 変化を計測することでバルジングを把握することも可能 である。 
そこで, 鋳片までの距離変位からバルジングを把握する 検知装置を開発した。な拀, 検知目標は, 鋳片までの距離 変位を分解能 $2 \mathrm{~mm}$ で測定し, $10 \mathrm{~mm}$ のバルジング量を検 知可能とすることとした，検知箇所は，角柱状鋳片の場 合, バルジングし易い鋳片断面の一辺の中央部とした。 な お，バルジングを検知する環境を Table 1 に示す.

\section{3. 検知方式}

検知方式は, 非接触として, Table 2 に示すように, レー ザ式, 渦流式, マイクロ波式, 超音波式の 4 種について調 查した1),2).

まず，渦流式は，モールド湯面レベル計の熱間 $1273 \mathrm{~K}$ 以上の環境で適用実績があるものの, 作動距離が短く, 距 離を離すと精度が悪くなるといった課題があり, 本件での 適用は困難であると判断した ${ }^{3)}$. 次に, マイクロ波式は, 熱間および粉塵雾囲気のような悪環境に強い測定方式で はあるが，マイクロ波を当てる測定対象面積が大きく，詳 細なプロファイルを測定するのは困難であった ${ }^{4}$. 超音波 式は, 空中伝播で考えた場合, 熱間雲囲気による大気密度 の変化が測定精度を悪くし, 水中伝播の場合, 測定経路に 水を維持する (例：水柱を形成する) 方法が必要で, 鋳片 を局部水冷して, 鋳片表面に新たな欠陥を生み出しかねな い. 最後に，レーザ式は，測定精度は満足するが，レーザ の送受光経路内に, 粉塵などによる遮蔽, 大気のゆらぎや 水蒸気による光の屈折があると, 精度に悪影響を与える. ただし，これらレーザ送受光経路を安定確保できれば，鋳 片までの距離変位が測定可能となる。

以上の結果より, 非接触での鋳片距離変位測定方法とし てレーザ式を採用した。また，同時に接触式の測定方法に ついても検討した。接触式については, 接触子を鋳片に接 触させ, 接触を検知したときに接触子の移動量がそのまま
鋳片までの変位量として測定することを基本原理とし, 独 自に開発した。

\section{4. 装置構成}

\section{1 非接触式}

非接触式の測定原理を Fig.1 に示す。構成は, レーザ光 を用いた距離計測器（以下，レーザ距離計という）に， レーザ距離計の送受光レンズ面の直前から鋳片に向かっ て延びるレーザ光経路保護管を取付け, さらに, 保護管に はバージガスを導入できる構造とした。

レーザ距離計には, 光の伝播時間を計測し距離を算出す る位相差測定方式を用いた ${ }^{5)}$.これは, 三角測距方式に比 べて, レーザの送受光経路範囲が狭く, 測定環境による精 度の影響が小さいためである ${ }^{2)}$.レーザ光経路保護管に は, 管内のレーザ光を邪魔する不純物をパージガスで除去 し，かつ，ガス導入口から管先端までを長くすることで, 管先端から鋳片までに層流のガス柱を形成するようにし， レーザ光経路を保護した. パージガスには, 鋳片の表面品 質に影響を与えない不活性のアルゴンガスを用い,レーザ 距離計の測定時のみ連続導入し, それ以外の場合は, 保護 管内に粉塵や水滴を堆積させない程度に, 間欠的に導入す るように制御した，また，保護管内へのガス導入時に，圧

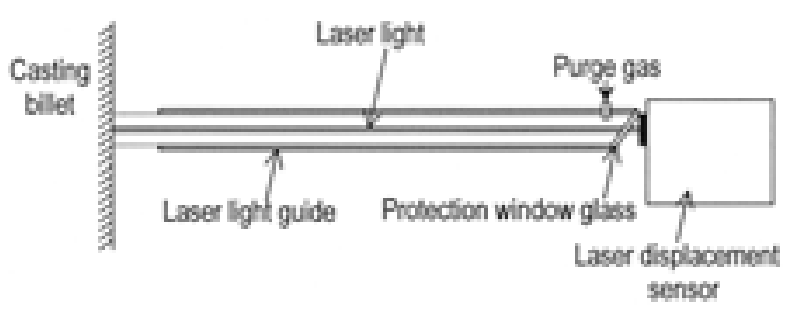

Fig.1. Principle of a non-contact method.

Table 1. Environment of bulging detection.

\begin{tabular}{l|l}
\hline Item & Specification \\
\hline Measurement position & Bottom of pinch rolls \\
\hline Atmosphere & $\begin{array}{l}\text { Drop of water, Coolant steam, } \\
\text { Radiant heat, Iron powder }\end{array}$ \\
\hline Temperature of casting billet & $1073 \sim 1473 \mathrm{~K}$ \\
\hline
\end{tabular}

Table 2. Comparison with displacement measurement methods.

\begin{tabular}{l|c|c|c}
\hline Method & Resolution $(\mathrm{mm})$ & Working distance $(\mathrm{m})$ & $\begin{array}{c}\text { Spot size of measured } \\
\text { area }(\mathrm{mm})\end{array}$ \\
\hline Laser & 1 & $0.1 \sim 10$ & 1 \\
\hline Eddy current & 0.04 & $\sim 0.01$ & 50 \\
\hline Microwave & 10 & $1 \sim 50$ & 400 \\
\hline Ultrasonic & 1 & $\sim 1.5$ & 10 \\
\hline
\end{tabular}


力一定で高圧を維持するために, ガス元栓から保護管まで の経路に増圧弁とガスタンクを組み合わせたものを取り 付けた.さらに, 保護管のレーザ距離計側の端は, 保護ガ ラスで密封されており, かつ, 保護ガラス面をレーザ光に 対して垂直から 30 度の角度を持たせている。これは，保 護ガラス面にレーザ光を邪魔する不純物を堆積しにくく するためと, ガラスの付着物によって，レーザ光が正反射 し，レーザ距離計の計測情報に誤差を与えないためであ る.また，ガラスの材質は，使用するレーザ光を減光させ ないよう，レーザ光波長 $650 \sim 690 \mathrm{~nm}$ に整合したものを 選択した。

\section{2 接触式}

接触式の測定原理を Fig.2 に示す．接触子は，移動量を 検出可能な直動機構で保持している.鋳片への接触を検知 するために, 接触子に, 伸縮機構, 伸縮に連動する近接ス イッチ，および，近接センサを設けた。これは，鋳片に接 触子が触れると, 接触子が縮み, それに連動した近接ス イッチが近接センサに接近すると, センサが信号を発し, 接触子が鋳片に接触したことを検知する。また，接触子内 部の管には, 接触子後端から冷却水を導入し, 接触子先端 から流れ出るようにしてある。

鋳造中の鋳片に接触する接触子は, 耐熱および耐食, 耐 摩耗性の材質を使用し, 先端に丸みを帯びた頭部を有する 管状のものとした。耐熱性と頭部の丸みについては, 接触 する鋳片が 1073 ～ $1473 \mathrm{~K}$ の超高温体であるため, 熱澎張 や熱ひずみが起こりにくい特性が必要で，かつ，鋳片に接 する面積を極力小さくするためである，また，接触子内部 を, 冷却水が流れ，先端から噴出するような管状としたの は, 接触子の冷却のためと, 鋳片との接触時に接触子によ る鋳片の損傷をなくすために, 鋳片との接触箇所を冷却凝 固させるためである. 接触子先端からの冷却水噴出は, 接 触子の先端に複数の細孔を開けシャワー状に噴出する方 法である. 移動量を検出可能な直動機構には, 電気信号の

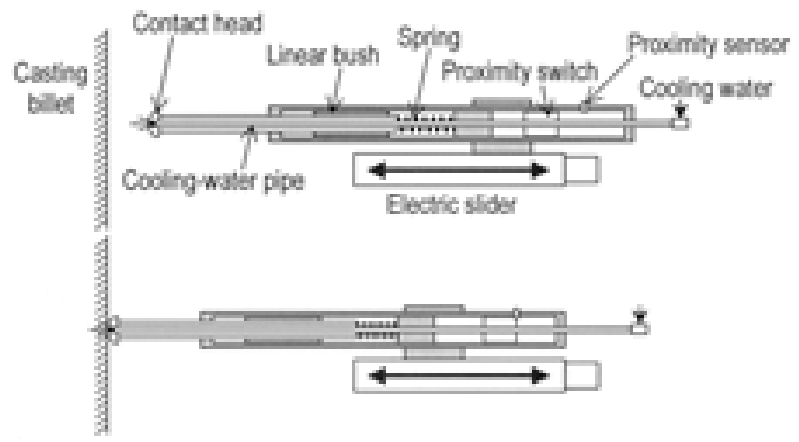

Fig.2. Principle of a contact method.
入出力で移動量を検出する電動スライダを用いた。 冷却水 は, 非接触式でのパージガスの導入方法と同様に, 接触子 が鋳片と接する時のみ連続導入し，それ以外の場合は，間 欠的に導入するように制御した.

\section{3 検知装置}

検知装置の装置構成を Fig.3に示す。構成は, 上記の非 接触式と接触式を一体にしたものである. また, 本装置に は, 測定部を測定待機位置および退避位置に前後進する機 構を有している。前後進機構には, 空圧シリンダを使用し ている。また，Fig.3では表示していないが，検査装置は， 装置全体をステンレス製の保護ケースで覆っている.ケー ス内に大気を送風するのは, 装置全体の空冷のためと, ケース内を正圧にし, 内部に水蒸気や粉塵の侵入を防止す るためである。

検知装置の信号系統の構成を Fig.4 に示す。装置駆動部 の制御, バルジング量の測定データ集録は, 全てパソコン で行っている．制御およびデータ集録ソフトは, 統合し て, LabVIEWで開発した.

このような装置を鋳造設備内に設置し, オンラインでの 測定実験を実施した. 次に, その実験方法および実験結果 について示す.

\section{5. 実験方法および実験結果}

\section{1 実験方法}

検知装置と鋳片との位置関係について Fig.5 に示す．検 知装置は, モールドとその直下にある鋳片拘束ロール群を 抜けた直後に設置し, 鋳片までの距離変位量を任意の一定 周期で断続的に測定した. 測定の開始は, 検知装置で測定 可能な位置まで，鋳片底部が引き抜かれた時からとした。 また，鋳片底部には，鋳造のはじめにモールド内で溶鋼を 受けるためのダミープレートと呼ばれる金属片があり,一 番最初の測定で，その金属片までの距離変位量を測定し， それを基準距離として, 基準距離に対する相対值を, 鋳片 長手方向のバルジング量として測定した.

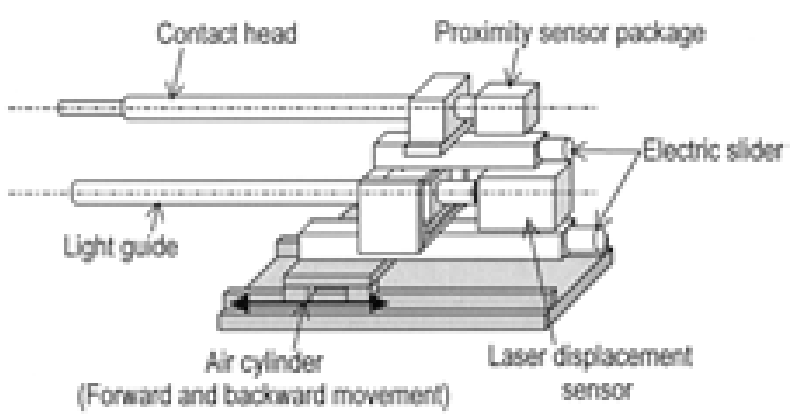

Fig.3. Bulging detecting device (prototype). 


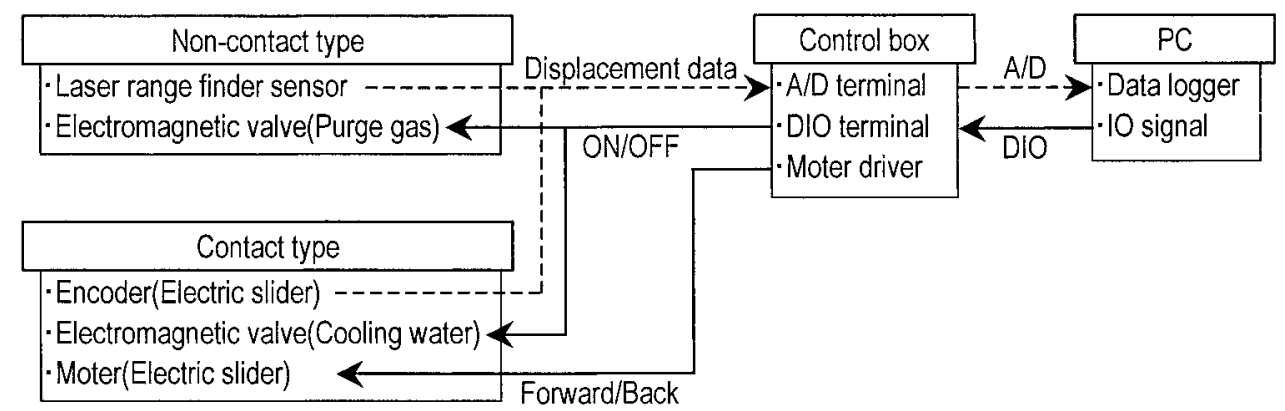

Fig.4. Signal processing of the bulging detecting device.

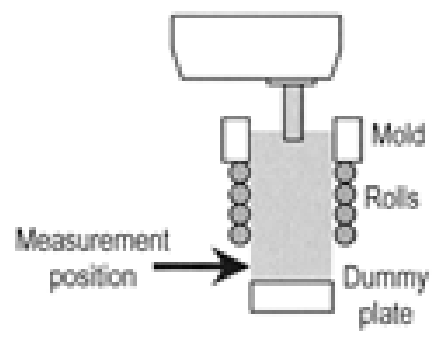

(a) Early stages of casting

Bulging on the dotted line is measured.

(b) Latter stages of casting

Fig.5. Measured position on casting billet.

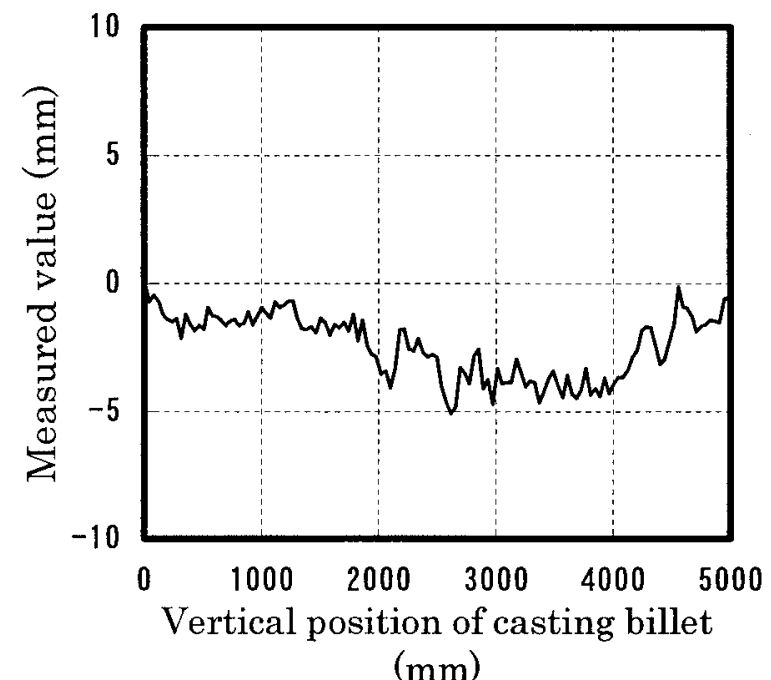

(a) Contact type data

\section{2 実験結果}

非接触式と接触式の測定結果を Fig. 6 に示すが, 非接触 式と接触式の測定結果を比較すると, 巨視的には, 両者の バルジング量変化に相関が見られ, 互いに同対象を測定し ているのがわかる. また, 微視的には, 非接触式の測定值 ばらつきが大きいのがわかる。この要因は，レーザ距離計 の測定精度（冷間時測定精度士 $0.5 \mathrm{~mm}$ ）と, レーザ光経 路保護管から鋳片までの空間において,レーザ光の遮蔽物 を完全に除去できなかったためである. 特に, 鋳片冷却水 の水滴の影響が大きい. 接触式の測定值ばらつきは小さ く, $3 \sigma$ で求めると, $1.847 \mathrm{~mm}$ であった. 非接触式の $3 \sigma$ は, $5.647 \mathrm{~mm}$ であり，この数值からも，非接触式のばら つきの大きさがわかる。

次に, Fig.7では, 測定したバルジング量と鋳造速度の 相関を示している.なお，このときのバルジング量は，接 触式の測定結果を用いた。この結果を見ると, 鋳造開始直

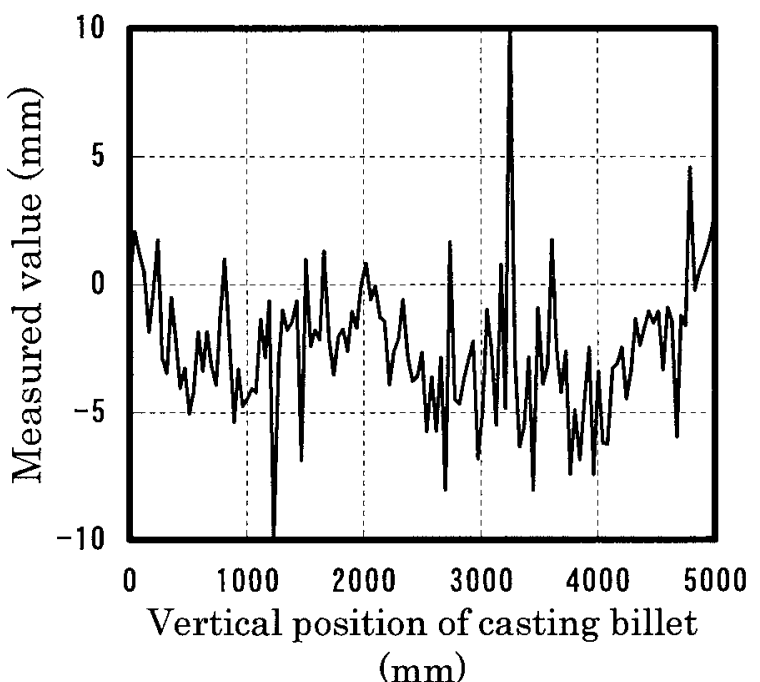

(b) Non-contact type data

Fig.6. Comparison of measured results between contact type and non-contact type. 


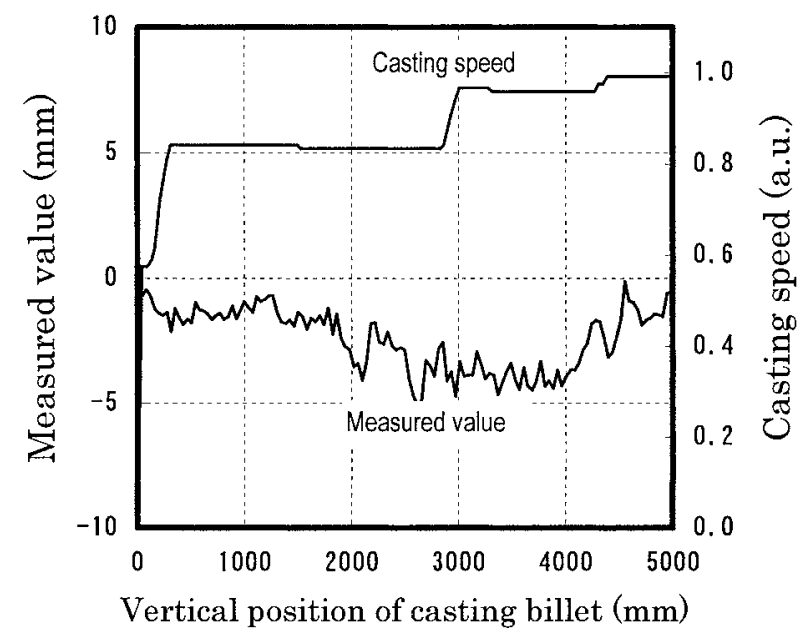

Fig.7. Correlation between measured value and casting speed.

後の鋳造速度上昇に伴い, バルジング量が基準距離に対し て減少しており,鋳片が膨らんできていることを示してい る。また，鋳造速度が一定になると，バルジング量もほぼ 一定に推移しているのがわかる. 以上のことから, バルジ ング量と鋳造速度には相関性があり，鋳造速度上昇に伴 い,バルジングすると推測される，なお，この傾向は，正 常に計測できた全ての実験（N=18）で見られた。

\section{6. 結 論}

連続鋳造設備において, 鋳片が拘束領域を抜けた後での バルジング量を検知する技術を開発した。

検知方式として, 非接触式と接触式の装置を開発し, オ ンラインでの測定実験を実施した. その結果, 非接触式の

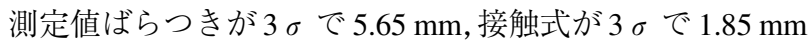
であり, オンラインでの実用には, 接触式が優位であると の結論が得られた。 また, 測定結果より, バルジング量と 鋳造速度には相関性があり, 鋳造速度上昇に伴い, バルジ ングすることが判った。

今後は, 本技術を利用して, 鋳片バルジング検知だけで なく, 鋳片断面を複数箇所測定し, 断面形状変化をインラ インで測定する技術などへの応用が期待される.

\section{（文 献）}

1) キーエンス2006総合:カタログ, 466.

2) キーエンス2006総合:カタログ, 738.

3) (株)ニレコ:カタログ, 渦流式溶鋼レベル計 ECLM-1000 Series.

4)(株)ワイヤーデバイス:カタログ, 高温設備用マイクロ波 距離計 マイクロレンジャー.

5) ジック(株):データシート, 距離測定器 DMEシリーズ. 